Scientia Marina 71(1)

March 2007, 57-64, Barcelona (Spain)

ISSN: 0214-8358

\title{
Spatial distribution and biomass of aquatic rooted macrophytes and their relevance in the metabolism of a Mediterranean coastal lagoon
}

\author{
BIEL OBRADOR, JOAN LLUÍS PRETUS and MARGARITA MENÉNDEZ \\ Departament d'Ecologia, Universitat de Barcelona, Av. Diagonal, 645, E-08028 Barcelona, Spain. \\ E-mail: obrador@ub.edu
}

\begin{abstract}
SUMMARY: This work aims to characterise the current autotrophic compartment of the Albufera des Grau coastal lagoon (Menorca, Balearic Islands) and to assess the relationship between the submerged macrophytes and the limnological parameters of the lagoon. During the study period the submerged vegetation was dominated by the macrophyte Ruppia cirrhosa, which formed dense extensive meadows covering $79 \%$ of the surface. Another macrophyte species, Potamogeton pectinatus, was also observed but only forming small stands near the rushing streams. Macroalgae were only occasionally observed. Macrophyte

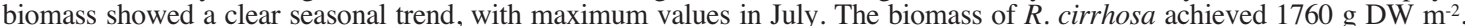
the highest biomass ever reported for this species in the literature. The seasonal production-decomposition cycle of the macrophyte meadows appears to drive the nutrient dynamics and carbon fluxes in the lagoon. Despite the significant biomass accumulation and the absence of a washout of nutrients and organic matter to the sea, the lagoon did not experience a dystrophic collapse. These results indicate that internal metabolism is more important than exchange processes in the lagoon.
\end{abstract}

Keywords: coastal lagoons, macrophytes, Ruppia cirrhosa, Western Mediterranean.

RESUMEN: DISTRIBUCIÓN ESPACIAL Y BIOMASA DE LOS MACRÓFITOS SUMERGIDOS Y SU RELEVANCIA EN EL METABOLISMO DE UNA LAGUNA LITORAL MEDITERRÁNEA. - El presente estudio pretende caracterizar el componente autotrófico de la laguna litoral de s'Albufera des Grau (Menorca, Islas Baleares) y determinar la relación entre los macrófitos acuáticos y la dinámica de los principales parámetros limnológicos del sistema. Durante el periodo estudiado, la vegetación sumergida estuvo dominada por el macrófito Ruppia cirrhosa, que formaba extensas praderas en toda la laguna. También se observó otra especie de macrófito, Potamogeton pectinatus, pero sólo formando pequeñas formaciones cerca de la entrada de los torrentes a la laguna. La biomasa de macrófitos mostró un claro ciclo estacional, con los valores máximos centrados en verano. La biomasa de $R$. cirrhosa alcanzó $1760 \mathrm{~g} \mathrm{DW} \mathrm{m}^{-2}$, que supone el valor más alto de biomasa descrito para esta especie en la literatura. El ciclo estacional de producción-descomposición de las praderas de macrófitos parece ser el responsable de la dinámica de nutrientes y de los flujos de carbono en la laguna. A pesar de las elevadas biomasas acumuladas y de la ausencia de un lavado de nutrientes y materia orgánica hacia el mar, la laguna no mostró un colapso distrófico, sugiriendo la importancia del metabolismo interno de la laguna por encima de los procesos de intercambio con el mar.

Palabras clave: lagunas litorales, macrófitos, Ruppia cirrhosa, Mediterráneo Occidental.

\section{INTRODUCTION}

Submerged aquatic macrophytes account for an important part of the primary production in shallow lakes (Margalef, 1983). In coastal lagoons, which are amongst the most productive ecosystems in the world (Barnes, 1980), the primary production is per- formed by macrophytes, macroalgae or, to a lesser extent, periphyton or phytoplankton (Castel et al., 1996; McGlathery et al., 2001). The dominance of one of these groups of primary producers can be related to nutrient levels, but many factors appear to be involved (Duarte, 1995; Taylor et al., 1995; Valiela et al., 1997). Nonetheless, the accumulation 
of significant biomass of either macroalgae or rooted macrophytes together with the highly dynamic character of coastal lagoons can periodically lead these systems to dystrophic crises (Castel et al., 1996; Viaroli et al., 1996; Duarte et al., 2002).

The Albufera des Grau is a coastal lagoon located on the northeast coast of Menorca, Balearic Islands. The lagoon is the most important wetland of the island and one of the most well preserved coastal lagoons of the western Mediterranean. The few previous studies of the Albufera des Grau described different submerged vegetation in its recent history (Margalef, 1952; Pretus, 1989; Cardona, 2001). In the early 1950s the eminent ecologist Ramon Margalef described the flora of the lagoon as Chaetomorpheto-Polysiphonietum, with no indication of the presence of aquatic submerged flowering plants (Margalef, 1952). During the 1980s the green macroalgae Chateomorpha crassa formed extensive beds covering $100 \%$ of the surface most of the time (Pretus, 1989). A dystrophic crisis was reported due to a massive mortality of macroalgal beds after the entrance of seawater to the lagoon and subsequent salinity changes (Pretus, 1989). The presence of rooted macrophytes in the lagoon was first reported in the 1990s in the seaward littoral areas, with an estimated cover of $40 \%$ (Cardona, 2001).

The lagoon is isolated in the sense that the communication with the sea does not imply an important water renewal of the system. This means that the export of organic matter and nutrients to the sea is not as important as it usually is in other lagoons (Duarte et al., 2002). In such a situation, we would expect the internal metabolism of the lagoon to play

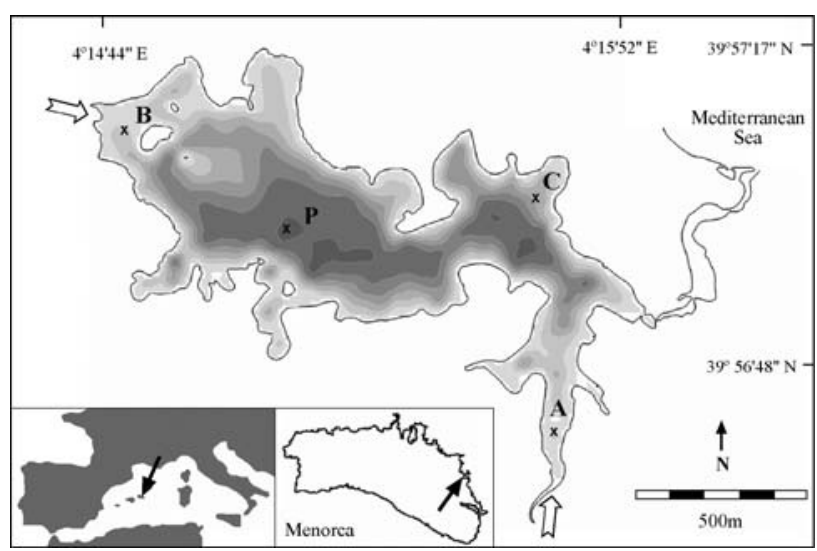

FIG. 1. - Location and bathymetric map of the Albufera des Grau in the island of Menorca, western Mediterranean. Isobaths are every $50 \mathrm{~cm}$. Sampling sites (crosses) and freshwater inputs (arrows) are shown. an important role in the trophic status of the system. Consequently, the knowledge of the trophic status including the relative importance of the different primary producers is essential for the understanding and further management of the lagoon.

This study aims to characterise the current autotrophic component of the lagoon and to assess the spatial and temporal variability of aquatic rooted macrophytes on a seasonal basis. A parallel description of the basic chemical parameters is also conducted to briefly discuss the relation of the production cycle with the metabolism of the lagoon.

\section{MATERIAL AND METHODS}

\section{Study site}

The Albufera des Grau has a surface area of 78 ha and a volume of $1 \mathrm{hm}^{3}$ (Fig. 1). The average depth is $1.37 \mathrm{~m}$ and it reaches a maximum depth of $3 \mathrm{~m}$ (Pretus, 1989). The climate is typically Mediterranean, with a mean air temperature of $17^{\circ} \mathrm{C}$ and an annual precipitation of $599 \mathrm{~mm}$ during the last three decades. The lagoon receives freshwater inputs from two streams that drain an area of 56 $\mathrm{km}^{2}$, the watershed being mainly composed of Palaeozoic siliciclastic sands and silts and Mesozoic dolomites. Freshwater inputs are irregular and centred on spring and autumn. The lagoon is connected to the sea by a narrow, $500 \mathrm{~m}$ long channel, Sa Gola, in which a small floodgate allows the lagoon-sea connection to be regulated when the sand-barrier is opened. The water of the lagoon is oligo-mesohaline with a salinity of between 5 and 20 during the last five years. There is a marked seasonality in the salinity and water level due to the Mediterranean evaporation/precipitation regime, which can potentially lead the system to critical situations such as hypersaline events (up to 60 in 1995, authors' unpublished data), haline stratification and dystrophic events (Pretus, 1989; Cardona, 2001).

\section{Sampling methods}

During the year 2000 the biomass of submerged macrophytes was determined at approximately monthly intervals at three littoral sites ( 1 m depth) beneath dense meadows. Sites A and B were located near the rushing streams, while site $\mathrm{C}$ was located on the northern coast of the lagoon (Fig. 1). Three 
replicates were conducted at each sampling site. Biomass samples were collected with a cylindrical core sampler of $16 \mathrm{~cm}$ diameter (Menéndez, 2002) and above-ground biomass was sorted by hand from the core. The sediment was sieved through a $1 \mathrm{~mm}$ mesh to collect below-ground biomass (rhizomes and roots). After sorting and cleaning with tap water, samples were dried $\left(70^{\circ} \mathrm{C}\right.$ to constant weight) and weighed.

Macrophyte cover was determined in July 2000 by visual observation from a boat. Repeated diving immersions were performed in order to identify macrophyte species when necessary. The surface of the lagoon was divided into a $50 \times 50 \mathrm{~m}$ grid, and the abundance of the macrophyte species was determined for each unit. The whole lagoon was surveyed. Macrophyte abundance was determined by a percent cover scale.

During the studied period the basic limnological parameters of the lagoon were determined monthly at a $3 \mathrm{~m}$ depth site in the central area of the lagoon. All samplings were conducted at the same time of the day. Five water samples were taken at different depths every $50 \mathrm{~cm}$ from surface to bottom. Water salinity, $\mathrm{pH}$, temperature and oxygen concentration were determined in situ with field sensors (WTW Multiline P3 and WTW Cond315i). Water samples were filtered, stored frozen and analysed in the laboratory as soon as possible. Nutrient concentration (nitrate, nitrite, ammonia, total phosphorus and SRP) were determined following standard methods (Hansen and Koroleff, 1999). Alkalinity was determined by potentiometric titration with $\mathrm{H}_{2} \mathrm{SO}_{4}$ and Gran evaluation (Stumm and Morgan, 1981). The parameters of the carbonate system (total dissolved inorganic carbon and partial pressure of $\mathrm{CO}_{2}$ ) were calculated from the $\mathrm{pH}$ and alkalinity values using the dissociation constants for seawater (Millero, 1995). Phytoplankton biomass was evaluated from pigment concentrations in water, which were extracted in $90 \%$ acetone and determined by the trichromatric method (Jeffrey and Humphrey, 1975).

\section{RESULTS}

\section{Spatial distribution and biomass of submerged vegetation}

Two vascular submerged macrophytes were found during the survey of aquatic vegetation in the lagoon, Ruppia cirrhosa (Petagna, Grande) and Potamogeton pectinatus L., which formed dense extensive meadows all along the lagoon. Occasional occurrence of red algae (Polysiphonia spp., Gracilaria sp.) and filamentous green algae (Chaetomorpha crassa) was observed. In the study site emerged macrophytes (Scirpus maritimus and Phragmites australis) were also observed in narrow vegetated belts in some areas along the shoreline.

The spatial extent of macrophytes was dominated by $R$. cirrhosa, which was widely distributed throughout the lagoon, forming the denser beds in the littoral parts (Fig. 2). Individual stands were also found at intermediate depths (1-2 m), with shoots reaching the surface. $R$. cirrhosa was only absent in the deepest part of the lagoon ( $>2 \mathrm{~m})$, and its total area of appearance was estimated to be $59 \mathrm{ha}$. On the other hand, P. pectinatus only appeared forming small stands among $R$. cirrhosa meadows and its distribu-

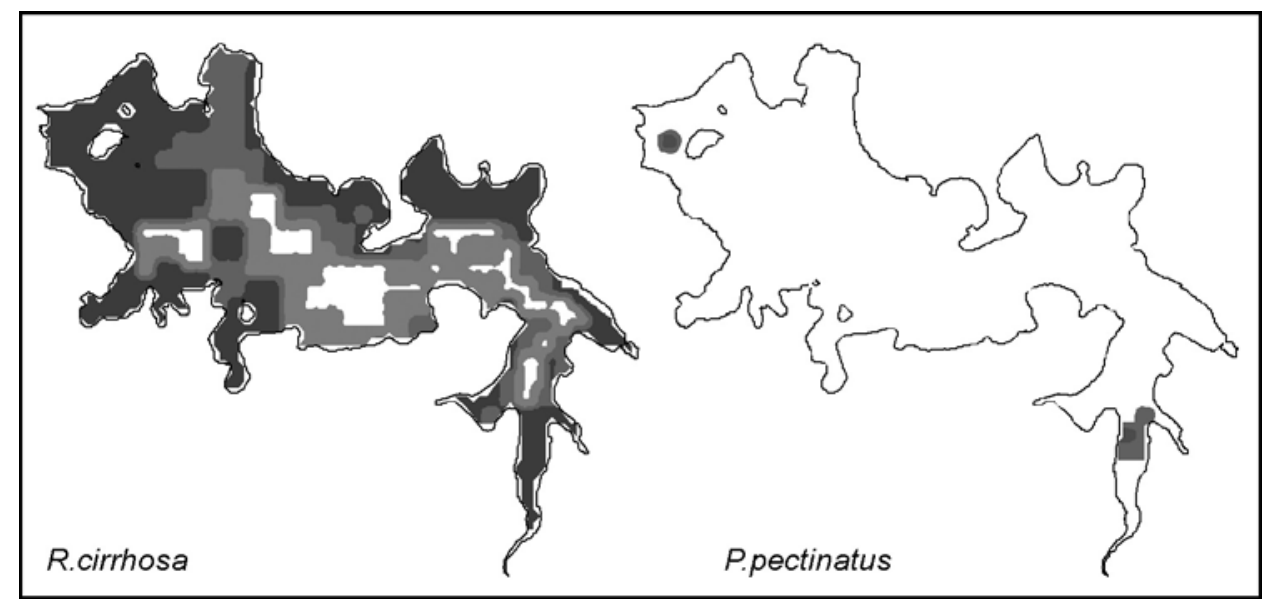

FIG. 2. - Spatial distribution of $R$. cirrhosa (left) and P. pectinatus (right) in summer 2000, including both living and recently desiccated littoral stands. Cover scale from dark grey to white: $100 \%,>50 \%,<50 \%$, and absence or scarce individuals. 


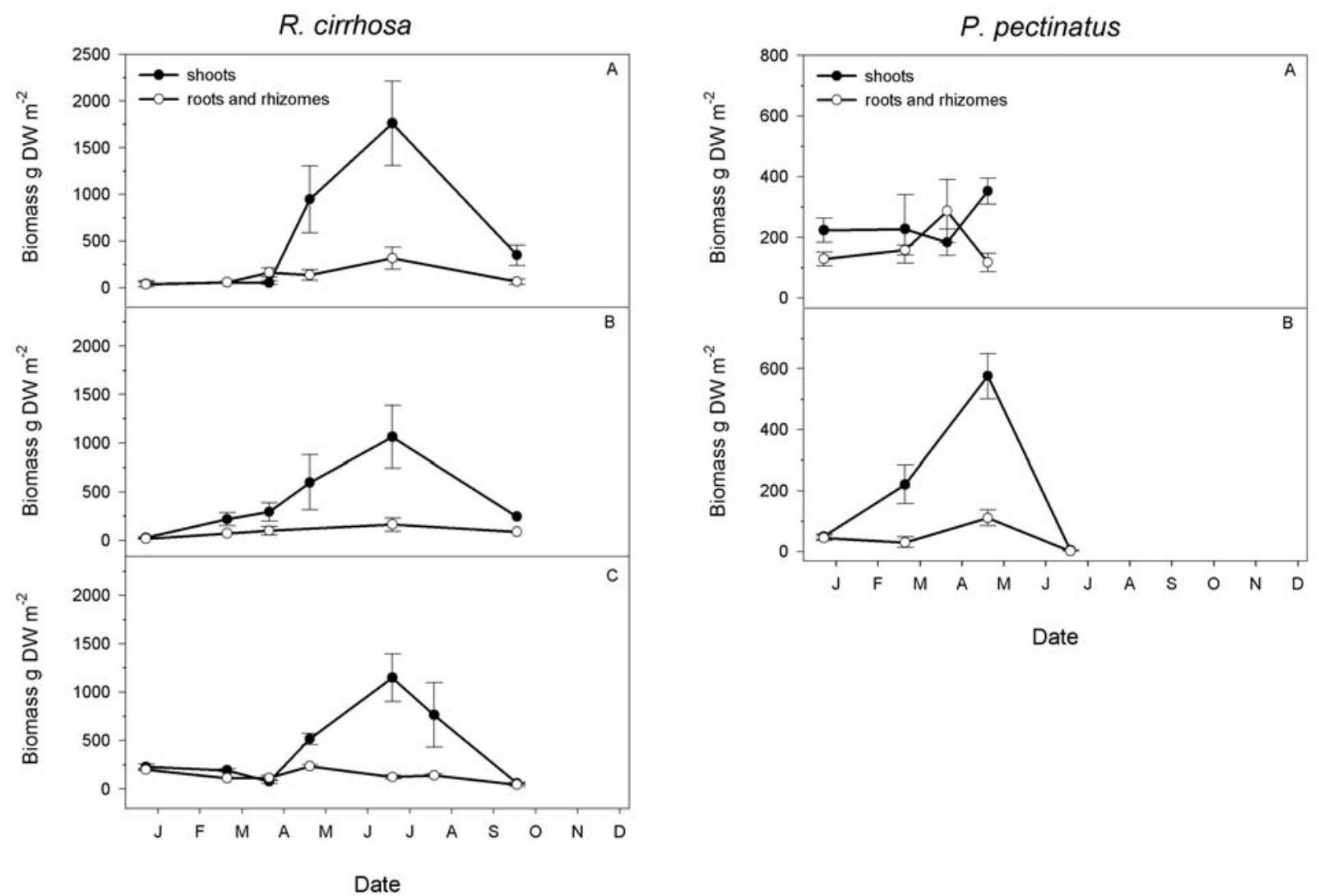

FIG. 3. - Temporal dynamics of $R$. cirrhosa (left) and P. pectinatus (right) biomass at the three sampling sites. Aboveground (filled circles) and belowground (open circles) biomass is shown.

tion was limited to the areas near the entrance of freshwater streams to the lagoon (Fig. 2).

Ruppia cirrhosa was present at the three sampling sites throughout the study period and showed a clear seasonal trend in terms of biomass at the three sampling sites (Fig. 3). Similar trends in aboveground (shoots and leaves) and belowground (roots and rhizomes) biomass were observed. Aboveground biomass was below $300 \mathrm{~g} \mathrm{DW} \mathrm{m}^{-2}$ from January to April. In spring increasing values of biomass were observed until July, when it peaked with more than $1000 \mathrm{~g} \mathrm{DW} \mathrm{m}^{-2}$ at the three sites. Maximum achieved biomass was $1760 \mathrm{~g} \mathrm{DW} \mathrm{m}^{-2}$ at site $\mathrm{A}$. The maximum belowground biomass was also observed in July at sites A and B, but was never above $300 \mathrm{~g} \mathrm{DW} \mathrm{m}^{-2}$. During the summer the contribution of belowground biomass to total biomass was very small, and aboveground biomass accounted for more than $85 \%$ of total plant biomass on average. Beyond the biomass maximum, $R$. cirrhosa progressively declined and both above and belowground biomass decreased, quickly reaching the low values of the previous winter (below $300 \mathrm{~g} \mathrm{DW} \mathrm{m}^{-2}$ ) and then absolutely disappearing from the lagoon.
Potamogeton pectinatus only appeared at sites A and B (Fig. 3). The maximum observed aboveground biomass of P. pectinatus was $576 \mathrm{~g} \mathrm{DW} \mathrm{m}^{-2}$ at site $\mathrm{B}$, representing $80 \%$ of total plant biomass. From the few data available, no clear seasonal trends can be inferred, but it disappeared completely from the lagoon after July.

\section{Water parameters}

During the study period, water level was always below sea level (s.l.) and showed clear seasonal fluctuations with extremely low values in summer (Fig. 4). The minimum level was reached in September, with $-85 \mathrm{~cm}$ below s.l., leading to major littoral desiccation. From the bathymetry of the lagoon (Pretus, 1989 and unpublished data) we were able to estimate the desiccated area at approximately 31 ha. This value accounts for $40 \%$ of the total lagoon surface and $90 \%$ of the surface corresponding to littoral areas $(<1 \mathrm{~m}$ depth). Average salinity was 17 , but great seasonal variation was observed (Fig. 4). The winter values of 12 progressively increased until October, when maximum salinity 


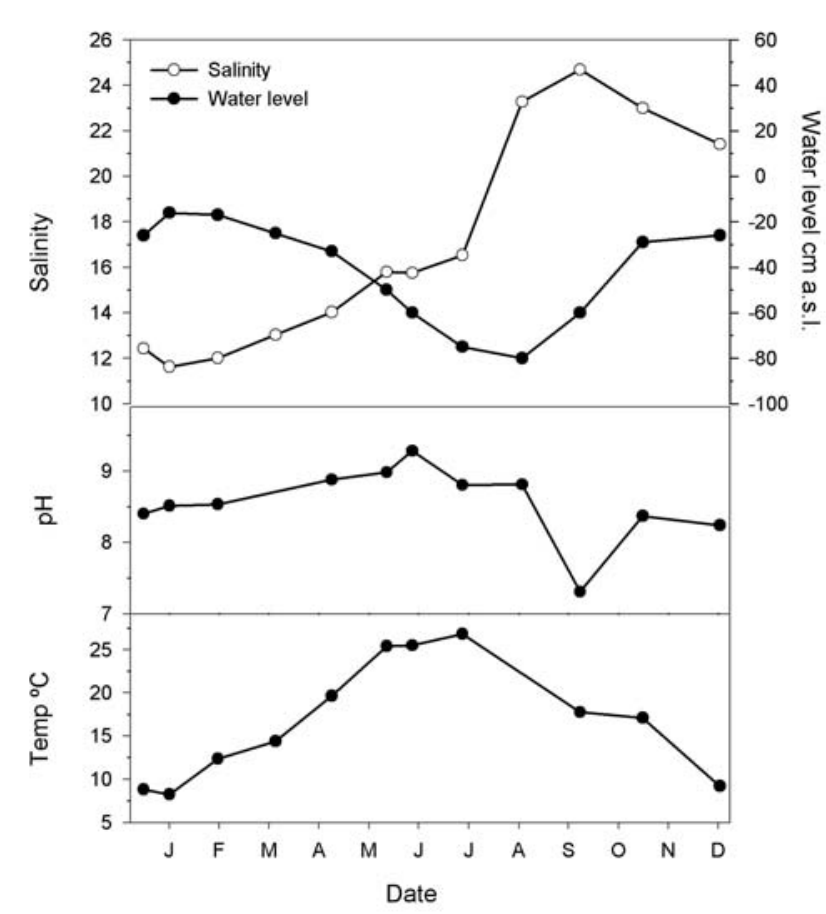

FIG. 4. - Temporal evolution of salinity, water level, $\mathrm{pH}$ and temperature during the study period.

was observed (25). This increase was related to the evaporation balance and to the sporadic entrance of small amounts of seawater into the lagoon due to low water levels. During the study period the water column was always mixed and only smooth vertical gradients in salinity were observed. A clear seasonal trend in $\mathrm{pH}$ was observed, with a slight progressive increase reaching the maximum of 9.3 in June (Fig. 4). A rapid decrease below seawater $\mathrm{pH}$ values was observed at the end of the summer. This variation in $\mathrm{pH}$ (range 7.3-9.3) occurred despite the high alkalinity of the water (Table 1).

TABLE 1. - Summary of water characteristics in s'Albufera des Grau

\begin{tabular}{lc}
\hline & range \\
\hline Water level $(\mathrm{cm}$ a.s.l) & \\
Volume $\left(\times 1000 \mathrm{~m}^{3}\right)$ & $-85-16$ \\
Salinity & $921-1026$ \\
Temperature $\left({ }^{\circ} \mathrm{C}\right)$ & $11.6-24.7$ \\
pH & $8.2-26.8$ \\
Oxygen $(\%$ saturation $)$ & $7.3-9.3$ \\
Oxygen $\left(\mathrm{mg} \cdot \mathrm{L}^{-1}\right)$ & $70-133$ \\
$\mathrm{Phosphorus} \mathrm{SRP}\left(\mu \mathrm{mol} \cdot \mathrm{L}^{-1}\right)$ & $6.7-12.2$ \\
$\mathrm{TP}\left(\mu \mathrm{mol} \cdot \mathrm{L}^{-1}\right)$ & $0.02-2.0$ \\
$\mathrm{NH}_{4}^{+}\left(\mu \mathrm{mol} \cdot \mathrm{L}^{-1}\right)$ & $0.26-5.34$ \\
$\mathrm{NO}_{3}^{-}\left(\mu \mathrm{mol} \cdot \mathrm{L}^{-1}\right)$ & $0-9.18$ \\
Alkalinity $\left(\mathrm{meq} \cdot \mathrm{L}^{-1}\right)$ & $0.30-4.62$ \\
$p C O_{2}(\mu \mathrm{atm})$ & $1.93-3.64$ \\
$\mathrm{HCO}_{3}^{-}\left(\mathrm{mmol} \cdot \mathrm{L}^{-1}\right)$ & $10-3870$ \\
$\mathrm{CO}_{2}\left(\mathrm{mmol} \cdot \mathrm{L}^{-1}\right)$ & $1.39-3.16$ \\
\hline
\end{tabular}

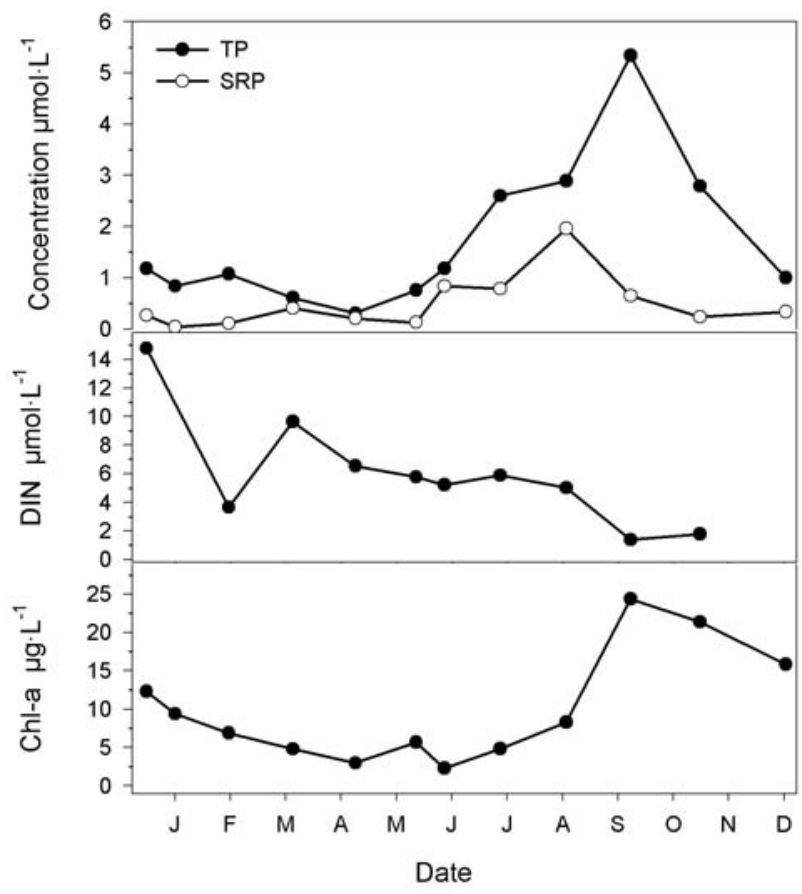

FIG. 5. - Temporal evolution of nutrient (total phosphorus, TP, SRP-phosphorus and dissolved inorganic nitrogen, DIN) and chlorophyll $a$ concentrations during the study period.

Nutrient concentrations were low during the study period (Table 1). Dissolved inorganic nitrogen, DIN, ranged from 1 to $15 \mu \mathrm{mol} \mathrm{L}^{-1}$ and a progressive reduction was observed during the year (Fig. 5). Soluble reactive phosphorus, SRP, showed a clear seasonal trend, peaking in summer $\left(2 \mu \mathrm{mol} \mathrm{L} \mathrm{L}^{-1}\right.$; Fig. 5). The total phosphorus, TP, including both dissolved and particulate forms of phosphorus, showed a similar trend (Fig. 5). The lowest values $\left(<1.5 \mu \mathrm{mol} \mathrm{L}^{-1}\right)$ were found during winter and spring months, and the concentration started a progressive increase from June. The maximum TP was achieved in October, with $5.3 \mu \mathrm{mol} \mathrm{L}^{-1}$. Chlorophyll $a$ concentration was at intermediate levels during the winter months (5-12 $\left.\mu \mathrm{g} \mathrm{L}^{-1}\right)$ and decreased during spring (Fig. 5). In July the concentration began to increase progressively and achieved the maximum value of $25 \mu \mathrm{g} \mathrm{L}^{-1}$ in October, when the eutrophic situation started to revert.

Interestingly, the dissolved inorganic carbon, DIC, showed a clear seasonal trend. During the growing period of $R$. cirrhosa, the DIC concentration showed a progressive decrease and $\mathrm{pCO}_{2}$ was below atmospheric equilibrium (Fig. 6). After the summer minimum DIC concentration, a huge increase was observed, presumably due to the release of carbon from macrophyte biomass decomposition. A fast and dramatic supersaturation of $\mathrm{CO}_{2}$ 


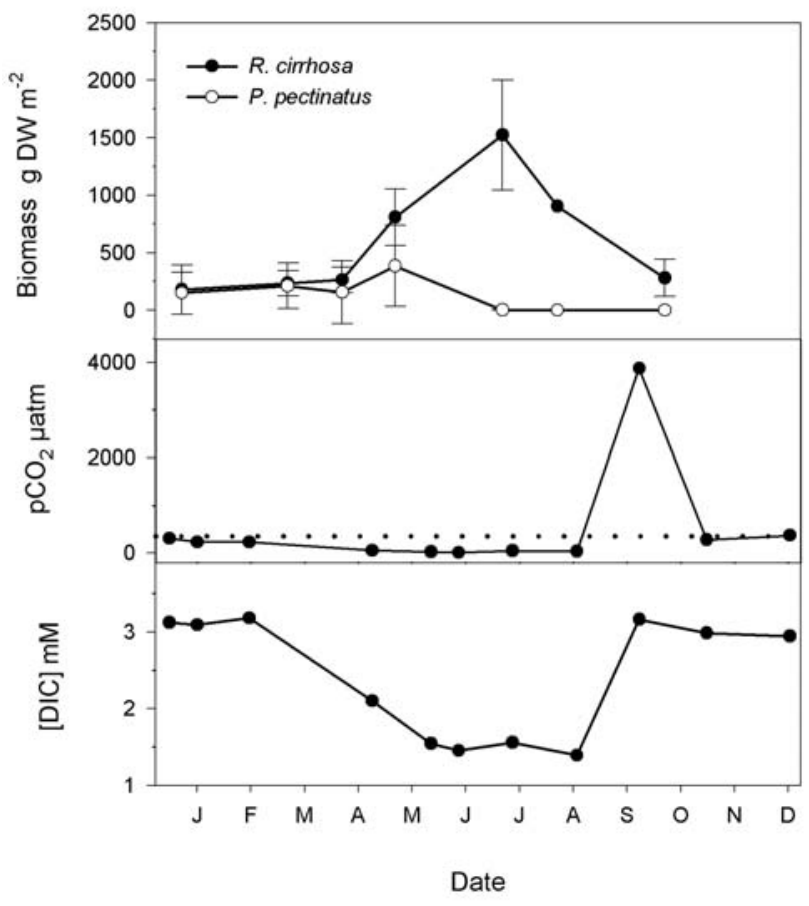

FIG. 6. - Temporal evolution of average total biomass of $R$. cirrhosa and $P$. pectinatus in relation with the partial pressure of $\mathrm{CO}_{2}$ and the concentration of dissolved inorganic carbon in water. Dotted line is the partial pressure of $\mathrm{CO}_{2}$ at atmospheric equilibrium.

in the lagoon occurred in October (up to $3870 \mu \mathrm{atm}$, ten times the atmospheric partial pressure), but two months later the $370 \mu \mathrm{atm}$ range of atmospheric equilibrium was recovered.

\section{DISCUSSION}

The Albufera des Grau is a macrophyte-dominated system in which $R$. cirrhosa is the most important species. The low diversity of macrophytes is typical of brackish-water systems (Remane and Schlieper, 1971). The Ruppia meadow is densely distributed throughout the lagoon, especially in the littoral areas. The total estimated macrophyte cover was $80 \%$ of the lagoon surface, of which only $2 \%$ corresponded to mixed Ruppia-Potamogeton meadows (Table 3). The dominance of $R$. cirrhosa over $P$. pectinatus is probably due to the salinity range observed in the lagoon, which is in accordance with the salinity tolerance of these species (Verhoeven, 1980a). Indeed, $P$. pectinatus disappears in July when salinity increases sharply from 16 to 23 .

The biomass of $R$. cirrhosa observed in this study is clearly the highest value ever reported for this species in the literature (Table 2) and indicates the importance of benthic production in the lagoon.
TABLE 2. - Range of biomass values reported in the literature for $R$. cirrhosa.

\begin{tabular}{|c|c|c|}
\hline $\begin{array}{l}\text { Biomass } \\
\mathrm{g} \mathrm{AFDW} \cdot \mathrm{m}^{-}\end{array}$ & Locality & Source \\
\hline $8-90^{\mathrm{a}}$ & Murcia, Spain & Ballester (1985) \\
\hline $20-106^{\mathrm{a}}$ & Certes fishponds, France & Viaroli et al (1996) \\
\hline $90-140$ & Tvärminne, Finland & Verhoeven (1980b) \\
\hline $50-160$ & Camargue, France & Verhoeven (1980b) \\
\hline $55-190$ & Coastal ponds, Netherlands & Verhoeven (1980b) \\
\hline $128-282$ & Badia del Fangar, Spain & Pérez and Camp (1986) \\
\hline $226-365^{a}$ & Buda lagoon, Spain & Menéndez et al. (2002) \\
\hline $72 \mathrm{a}-438$ & St. André lagoon, Portugal & Duarte et al. (2002) \\
\hline $473-642^{\mathrm{a}}$ & Fra Ramon, Spain & Gesti et al. (2005) \\
\hline $75-672$ & Tancada Lagoon, Spain & Menéndez (2002) \\
\hline $380-1408^{a}$ & Albufera des Grau, Spain & This study \\
\hline
\end{tabular}

Such high biomass may be related to the high irradiance and warm temperatures typical of the Mediterranean climate. Moreover, in a situation without light limitation, the greater depth of the littoral areas of the Albufera des Grau in comparison with other reported Mediterranean coastal lagoons could presumably be involved in the achievement of such high biomass values.

A clear seasonal trend in the production and decomposition of the Ruppia meadows was observed at the three sampling sites, which only differed in the maximum values of Ruppia biomass. The lower biomass at site $\mathrm{B}$ may be related to the high biomass of $P$. pectinatus at the sampling site (Fig. 3) but further work is required to confirm this assumption (Verhoeven, 1980a; Menéndez et al., 2002). Similarly, the lower biomass at site $\mathrm{C}$ may be related to differences in sediment composition and to the presence of macroalgae at the sampling site $\left(346 \mathrm{~g} \mathrm{DW} \mathrm{m}^{-2}\right.$ of Polysiphonia sp., authors' unpublished data).

The macrophyte production-decomposition cycle seems to drive most of the limnological parameters of the lagoon. During the macrophyte growing period nutrient concentrations are low, presumably limiting phytoplankton growth. From mid-summer the macrophyte beds decline and decomposition of macrophyte

TABLE 3. - Comparison of macrophyte cover and percentage of cover of each species in years 2000 and 2001

\begin{tabular}{lcc}
\hline & 2000 & 2001 \\
\hline Macrophyte cover (ha) & 59 & 64 \\
Percentage of total surface (\%) & & \\
absence of macrophytes & 21 & 15 \\
monospecific meadows of $R$. cirrhosa & 77 & 85 \\
$R$. cirrhosa - P. pectinatus & 2 & 0 \\
monospecific meadows of P. pectinatus & 0 & 0 \\
\hline
\end{tabular}


biomass takes place (Menéndez et al., 2003), as suggested by the increase in SRP and DIC in the water column. The increase in DIC is actually delayed in relation to SRP and could also be related to carbonate dissolution due to low $\mathrm{pH}$. On the other hand, a fast release of nutrients is expected due to the high decomposition rate of $R$. cirrhosa biomass (Menéndez et al., 2003; Menéndez et al., 2004). The average expected time to decompose $50 \%$ of $R$. cirrhosa biomass in the Albufera des Grau is 2 months (calculated from measured decomposition rates in the Albufera des Grau, authors' unpublished data), and the whole macrophyte community is mineralised after a year cycle (230 days to decompose the $95 \%$ of biomass).

The nutrient release is presumably responsible for the autumn proliferation of phytoplankton, as suggested by the synchronous peak in chlorophyll $a$ and TP concentrations. The increase in TP could be explained by a release of SRP from the sediments due to low $\mathrm{pH}$, but such an increase in SRP was not observed and SRP actually decreased. This observation, together with the increase in chlorophyll $a$, strongly suggests that SRP is incorporated into phytoplankton and that the peak in TP is thus reflecting phytoplankton growth. The constant or even decreasing DIN, which is synchronous with the increase in SRP, may be due to a fast incorporation of nitrogen into phytoplankton or due to denitrification beneath the dense littoral meadows. Thus, anoxic conditions near the bottom are expected to be common in the littoral areas with large amounts of biomass (Calado and Duarte, 2000). However, the system did not fall into dystrophy as no hypoxia was observed in the open water (the oxygen saturation concentration in the open waters never decreased below $70 \%$; Table 1).

The great reduction of DIC during the macrophyte growing period may cause both phytoplankton and macrophytes to be limited by carbon. Indeed, the minimum $\mathrm{CO}_{2}$ concentration was below the compensation point described for $R$. cirrhosa (Table 1, Peñuelas and Menéndez, 1990). R. cirrhosa, however, is highly adapted to low $\mathrm{CO}_{2}$ values because of its ability to use $\mathrm{HCO}_{3}^{-}$(Peñuelas and Menéndez, 1990; Hellblom and Axelsson, 2003). Nonetheless, a $\mathrm{HCO}_{3}^{-}$concentration below $R$. cirrhosa's compensation point have been observed in the littoral waters of the Albufera des Grau on a typical summer daily cycle, suggesting growth limitation by inorganic carbon during extremely productive periods (authors' unpublished data).
With regard to the important role that macrophyte meadows play in the lagoon carbon cycle, the question of the stability of such a productive system in relation to the fluctuating physical factors (salinity and water level) emerges. In summer 2001 a new macrophyte mapping was conducted in order to evaluate the recovery of the meadows after the littoral desiccation of the previous summer. In 2001 only monospecific meadows of $R$. cirrhosa were observed, with no presence of $P$. pectinatus. This may be due to the higher salinities observed during the growing period (up to 14-20, unpublished data). As in 2000, dense stands of $R$. cirrhosa occupied littoral areas and sparse individuals were found in the central part of the lagoon. The total meadow area was estimated at 64 ha (Table 3), slightly higher than that observed in 2000 . This expansion of $R$. cirrhosa, despite the very low water levels of the previous year, is consistent with the high tolerance to desiccation described for this species (Adams and Bate, 1994; Gesti et al., 2005).

In conclusion, despite the magnitude of carbon fluxes in the lagoon, as exemplified by the huge $\mathrm{pCO}_{2}$ increase in autumn, the system did not collapse into a dystrophic crisis, as would probably have been the case in a macroalgae-dominated situation in which a faster return of nutrients is expected (Viaroli et al., 1996, Viaroli and Christian, 2003). The phytoplankton proliferation due to nutrient release did not achieve extreme chlorophyll $a$ concentrations. Because the water level was below s.l. throughout the year, no outputs to the sea occurred. Consequently, the fast recovery of spring conditions (low phytoplankton and nutrient levels and $\mathrm{pCO}_{2}$ near atmospheric equilibrium) occurred without the washout of nutrients or organic matter to the sea, and was more related to the internal metabolism of the lagoon. This is in discordance with other similar systems where an export of organic matter and nutrients to the sea or even a harvesting of macrophyte biomass help prevent eutrophication (Calado and Duarte, 2000; Duarte et al., 2002).

\section{ACKNOWLEDGEMENTS}

This work was partially funded by the Albufera des Grau Nature Park. We are especially grateful to Miquel Truyol for his assistance during field work and to George Swann for the English corrections. We also thank Dr. Xavier Quintana and an anonymous reviewer for their valuable comments. 


\section{REFERENCES}

Adams, J. and G. Bate. - 1994. The tolerance to desiccation of the submerged macrophytes Ruppia cirrhosa (Petagna) Grande and Zostera capensis Setchell. J. Exp. Mar. Biol. Ecol., 183: 53-62.

Ballester, R. - 1985. Biomasa, estacionalidad y distribución de tres macrófitos: Ruppia cirrhosa, Cymodocea nodosa y Caulerpa prolifera en el Mar Menor (Murcia, SE Spain). Anal. Biol., 4, 31-36.

Barnes, R.S.K. - 1980. Coastal lagoons. Cambridge University Press, Cambridge.

Calado, G. and P. Duarte. - 2000. Modelling growth of Ruppia cirrhosa. Aquat. Bot., 68: 29-44.

Cardona, L. - 2001. Non-competitive coexistence between Mediterranean grey mullet: evidence from seasonal changes in food availability, niche breadth and trophic overlap. J. Fish Biol., 59: 729-744.

Castel, J., P. Caumette and R. Herbert. - 1996. Eutrophication gradients in coastal lagoons as exemplified by the Bassin d'Arcachon and the Etang du Prévost. Hydrobiologia, 329: ix-xxviii.

Duarte, C. -1995 . Submerged aquatic vegetation in relation to different nutrient regimes. Ophelia, 41: 87-112.

Duarte, P., J.M. Bernardo, A.M. Costa, F. Macedo, G. Calado and L. Cancela da Fonseca. -2002. Analysis of coastal lagoon metabolism as a basis for management. Aquat. Ecol., 36: 3-19.

Gesti, J., A. Badosa and X. Quintana. - 2005. Reproductive potential in Ruppia cirrhosa (Petagna) Grande in response to water permanence. Aquat. Bot., 81: 191-198.

Hansen, H. and F. Koroleff. - 1999. Determination of nutrients. In: K. Grasshoff, K. Kremling and M. Ehrhardt (eds.), Methods of seawater analysis, pp. 159-228. Wiley-VCH, Wenheim

Hellblom, F. and L. Axelsson. - 2003. External HCO3- dehydration maintained by acid zones in the plasma membrane is an important component of the photosynthetic carbon uptake in Ruppia cirrhosa. Photosynth. Res., 77: 173-181.

Jeffrey, S. and G. Humphrey. - 1975. New spectrophotometric equations for determining chlorophyll a,b,c1, and c2 in higher plants, algae and phytoplankton. Biochem. Physiol. Pflanzen, 167: 191-194.

Margalef, R. - 1952. Materiales para la hidrobiología de la isla de Menorca. Pub. Inst. Biol. Apl., XI: 5-112.

Margalef, R. - 1983. Limnología. Omega, Barcelona.

McGlathery, K.J., I.C. Anderson and A.C. Tyler. - 2001. Magnitude and variability of benthic and pelagic metabolism in a temperate coastal lagoon. Mar. Ecol. Prog. Ser., 216: 1-15.

Menéndez, M. - 2002. Net production of Ruppia cirrhosa in the Ebro Delta. Aquat. Bot. 73: 107-113.

Menéndez, M., O. Hernández and F.A. Comín. - 2002. Spatial distribution and ecophysiological characteristics of macrophytes in a Mediterranean coastal lagoon. Estuar. Coast. Shelf Sci., 55 : 403-413.

Menéndez, M., D. Carlucci, M. Pinna, F.A. Comín and A. Basset. 2003. Effect of nutrients on decomposition of Ruppia cirrhosa in a shallow coastal lagoon. Hydrobiologia, 506-509: 729-735.

Menéndez, M., O. Hernandez, N. Sanmartí and F.A. Comín. - 2004. Variability of organic matter processing in a Mediterranean coastal lagoon. Int. Rev. Hydrobiol., 89: 476-483.

Millero, F.J. - 1995. Thermodynamics of the carbon dioxide system in the oceans. Geochim. Cosmochim. Acta, 59: 661-677.

Peñuelas, J. and M. Menéndez. - 1990. HCO3- as an exogenous carbon source for Ruppia cirrhosa (Petagna) Grande. Arch. Hydrobiol., 120(1): 89-96.

Pérez, M.J. and J. Camp. - 1986. Distribución espacial y biomasa de las fanerógamas marinas de las bahías del Delta del Ebro. Inv. Pesq., 50: 519-530.

Pretus, J.L. - 1989. Limnología de la Albufera de Menorca (Menorca, España). Limnetica 5: 69-81.

Remane, A. and C. Schlieper. - 1971. Biology of brackish water. John Wiley and Sons, New York.

Stumm, W. and J. Morgan. - 1981. Aquatic chemistry. John Wiley and Sons, New York.

Taylor, D.I., S.W. Nixon, S.L. Granger, B.A. Buckley, J.P. McMahon and H.J. Lin. - 1995. Responses of coastal lagoon plant communities to different forms of nutrient enrichment - a mesocosm experiment. Aquat. Bot., 52: 19-34.

Valiela, I., J. McClelland, J. Hauxwell, P.J. Behr, D. Hersh and K. Foreman. - 1997. Macroalgal blooms in shallow estuaries: controls and ecophysiological and ecosystem consequences. Limnol. Oceanogr., 42: 1105-118.

Verhoeven, J. - 1980a. The ecology of Ruppia-dominated communities in western Europe. II. Synecological classification, structure and dynamics of the macroflora and macrofauna communities. Aquat. Bot., 8: 1-85.

Verhoeven, J. - 1980b. The ecology of Ruppia-dominated communities in western Europe. III. Aspects of production, consumption and decomposition. Aquat. Bot., 8: 209-253.

Viaroli, P., M. Bartoli, C. Bondavalli, R Christian, G. Giordani and M. Naldi. - 1996. Macrophyte communities and their impact on benthic fluxes of oxygen, sulphide and nutrients in shallow eutrophic environments. Hydrobiologia, 329: 105-119.

Viaroli, P. and R. Christian. - 2003. Description of trophic status, hyperautotrophy and dystrophy of a coastal lagoon through a potential oxygen production and consumption index-TOSI: Trophic Oxygen Status Index. Ecol. Indic., 3: 237-250.

Scient. ed.: E. Ballesteros.

Received February 13, 2006. Accepted September 26, 2006.

Published online February 6, 2007. 